\title{
ANALISIS DAN PERANCANGAN SISTEM INFORMASI MANAJEMEN SURAT MASUK DAN SURAT KELUAR PADA DINAS KEPENDUDUKAN DAN PENCATATAN SIPIL KOTA JAMBI
}

\author{
Emilia Muchtar $^{1}$, Effiyaldi $^{2}$ \\ Program Studi Magister Sistem Informasi, STIKOM Dinamika Bangsa, Jambi \\ Jl. Jendral Sudirman, Kec. The Hok, (0741) 35095 \\ E-mail:1.emilmuchtarjambi@gmail.com ${ }^{1}$, effiyaldi67@stikom-db.ac.id ${ }^{2}$
}

\begin{abstract}
Currently in the making or filing letters to the Department of Population and Civil Registrar of Jambi City there are still some obstacles such as making incoming mail reports, outgoing mail reports, recap reports, as well as when checking the report in certain period, searching documents that have been stored is still difficult and takes longer time because those old documents must be rechecked and reopened, and oftentimes the difficulty comes when we need to make a final recap of the report during a period when they are needed the most. Therefore, the author provide solutions in the form of information systems management to manage incoming and outgoing mail. This is helpful to facilitate employees in processing data of incoming and outgoing mail and simplify the searching and the reports making processes. In this research, the author uses UML (Unified Modeling Language) tool, Prototype model and VB.NET language as a tool for making the design. In which the expected results are in the form of system design that can make the searching and reports making processes easier and faster.
\end{abstract}

Keywords: Analysis, Design, System, Information, management, incoming mail, outgoing mail

\begin{abstract}
Abstrak
Saat ini dalam pembuatan atau pengarsipan surat pada Dinas Dukcapil Kota Jambi masih terdapat beberapa kendala seperti pembuatan laporan surat masuk, laporan surat keluar, laporan rekapan, maupun saat akan melihat laporan sesuai periode yang diinginkan, pencarian dokumen yang telah tersimpan saat ini masih sulit dan lama karena harus membuka dokumen-dokumen lama dan mencari satu persatu dan sering kesulitan saat akan membuat rekapan akhir pada periode yang dibutuhkan,. Oleh karena itu penulis memberikan solusi berupa rancangan sistem informasi managemen surat masuk dan surat keluar. agar mempermudah pegawai dalam mengolah data surat masuk dan surat keluar dan mempermudah dalam pencarian data serta pembuatan laporan. Dalam penelitian ini peneliti menggunakan Tool UML (Unified Modeling Language), model Prototype dan menggunakan bahasa VB.NET sebagai tool untuk membuat perancangan. Dimana hasil yang diharapkan adalah berupa rancangan sistem yang dapat membuat sistem pencarian lebih cepat dan pembuatan laporan lebih mudah dan cepat.
\end{abstract}

Kata Kunci : Analisis, perancangan, sistem, informasi, manajemen, surat masuk, surat keluar

(C) 2019 Jurnal Manajemen Sistem Informasi.

\section{Pendahuluan}

Perkembangan teknologi dan informasi yang kita rasakan sekarang ini membawa pengaruh besar, khususnya dalam dunia kerja. Salah satunya yaitu penggunaan komputer yang dapat mempermudah serta memperlancar pekerjaan.

Komputer dalam dunia usaha baik perusahaan swasta maupun instansi pemerintah berperan sebagai hardware yang menjalankan software yang dapat dimengerti oleh pengguna. Pada instansi pemerintah penggunaan komputer dapat diterapakan dalam menata arsip agar lebih rapi dan mudah dalam

Jurnal Manajemen Sistem Informasi Vol.4, No.2, Juni 2019 
pencariannya. Menurut Kanisius (2008 : 92), arsip adalah suatu kumpulan warkat (setiap catatan tertulis/bergambar yang memuat keterangan mengenai suatu hal atau peristiwa yang dibuat orang untuk membantu mengingatnya yang disimpan secara sistematis karena mempunyai suatu kegunaan agar setiap kali diperlukan dapat secara cepat ditemukan kembali.

Pada saat ini, prosedur yang diterapkan pada manajemen surat masuk dan surat keluar pada Bagian Umum Sekretariat Dukcapil Kota Jambi mulai dari penerimaan, pembuatan, penyimpanan, pendokumentasian, hingga verifikasi surat, semua dilakukan secara konvesional. Dokumentasi surat masuk dan keluar hanya berupa penulisan di buku besar. Sedangkan pada tahap pengarsipan surat hanya berupa penyimpanan dokumen hardcopy. Penerapan metode tersebut, dirasakan oleh pegawai PTT Dinas Dukcapil Kota Jambi yang bertugas di Bagian Umum Sekretariat Dukcapil yaitu bernama Christin Apriyani yang merasakan manajemen surat masuk dan surat keluar Bagian Umum Sekretariat Dukcapil Kota Jambi kurang efektif dan efisien. Di antaranya adalah pencarian dokumen lama sulit sebab harus membuka terlebih dahulu data-data lama dan mencarinya satu persatu. Kesulitan dalam laporan surat masuk dan surat keluar, hilang dan rusaknya dokumen, status surat yang belum dapat di monitor oleh pemohon surat membutuhkan waktu lama dalam pembuatan surat keluar maupun disposisi.

Dengan adanya masalah yang telah disebutkan di atas, bagian umum sekretariat Dukcapil Kota Jambi di rasa perlu untuk merubah metode manajemen persuratan yang saat ini mereka gunakan, yaitu metode konvensional menjadi metode manajemen persuratan yang tekomputerisasi dan otomatis. Pengarsipan surat dilakukan secara elektronik, yaitu penyimpanan dokumen softcopy dan dilengkapi dengan laporan surat masuk dan surat keluar baik perhari maupun per periode. Selain itu aplikasi ini juga membantu melakukan monitoring terhadap disposisi surat pada tahap verifikasi. Serta penerimaan surat masuk dan surat keluar akan dikirim juga melalui elektronik mail (e-mail).

Berdasarkan hal tersebut diatas, penulis mengusulkan sebuah perancangan sistem informasi manajemen surat masuk dan surat keluar untuk Dinas Kependudukan dan Pencatatan Sipil Kota Jambi yang sesuai dengan kebutuhannya. Dalam perancangan sistem informasi tersebut menggunakan UML (Unifed Modelling Language), dimana pemodelan ini merupakan alat bantu dalam pengembangan sistem yang berorientasi objek yang menyediakan bahasa pemodelan visual yang memungkinkan bagi pengembangan sistem informasi, maka dari itu, berdasarkan beberapa masalah tersebut diatas penulis tertarik melakukan penelitian dengan judul “ ANALISIS DAN PERANCANGAN SISTEM INFORMASI MANAJEMEN SURAT MASUK DAN SURAT KELUAR PADA DINAS KEPENDUDUKAN DAN PENCATATAN SIPIL KOTA JAMBI".

\section{Landasan Teori dan Tinjauan Pustaka}

\subsection{Landasan Teori \\ 2.1.1 Pengertian Perancangan Sistem}

Pressman, Roger S (2010 ; 291), mengatakan : "Perancangan sesungguhnya merupakan suatu aktivitas rekayasa perangkat lunak yang dimaksudkan untuk membuat keputusan-keputusan utama sering kali bersifat struktural".

Rizky, Soetam (2011; 140), mendefinisikan bahwa : "Perancangan adalah sebuah proses untuk mendefinisikan sesuatu yang akan dikerjakan dengan menggunakan teknik yang bervariasi serta didalamnya melibatkan deskripsi mengenai arsitektur serta detail komponen dan juga keterbatasan yang akan dialami dalam proses pengerjaannya".

Rosa dan Shalahuddin $(2013 ; 23)$, mendefenisikan bahwa : "Perancangan dalam pembangunan perangkat lunak merupakan upaya untuk mengonstruksi sebuah sistem yang memberikan kepuasan akan spesifikasi kebutuhan fungsional, memenuhi target, memenuhi kebutuhan secara implisit atau eksplisit dari segi performansi maupun penggunaan sumber daya, kepuasan batasan pada proses desain dari segi biaya, waktu dan perangkat.

Berdasarkan pengertian diatas dapat disimpulkan bahwa perancangan adalah suatu tahap yang dilakukan untuk menentukan bagaimana suatu sistem menyelesaikan permasalahan yang ada, dengan mengatur komponen dalam sistem tersebut sehingga sistem dapat bekerja sebagaimana yang diharapkan. 


\subsection{Tinjauan Pustaka}

Penelitian sejenis yang sudah ada adalah penelitian yang dilakukan oleh Siska Wahyu Kartikasari, namun penelitian yang penulis lakukan ini memiliki perbedaan dibandingkan dengan penelitian tersebut. Faktor pembeda dari penelitian tersebut adalah sebagai berikut :

1. Topik Permasalahan

Penelitian ini mengangkat permasalahan yang berbeda dimana peneliti sebelumnya mengenai sistem pengelolaan surat masuk dan surat keluar pada UPT Taman Kanak-kanak dan Sekolah Dasar sedangkan penulis mengenai analisis dan perancangan sistem manajemen surat masuk dan surat keluar.

2. Lokasi Penelitian

Studi kasus diambil dari lokasi penelitian berbeda, dimana peneliti sebelumnya menggunakan UPT

Taman Kanak-kanak dan Sekolah Dasar Kecamatan Pringkuku. Sedangkan pada penelitian ini penulis menggunakan studi kasus pada Kantor Dinas Kependudukan dan Pencatatan Sipil Kota Jambi.

Penelitian ini memiliki persamaan yaitu sama-sama focus pada Manajemen ataupun pengarsipan Surat Masuk dan Surat Keluar pada masing-masing instansi atau pun perusahaan. Penelitian yang penulis lakukan memiliki relevansi dengan penelitian Siska Wahyu Kartikasari yang tertuang dalam jurnal Sentra Penelitian Engineering dan Edukasi Volume 3 No 1-2011 dengan judul "Sistem Informasi Pengelolaan Surat Masuk dan Surat Keluar Pada Unit Perlaksanaan Taman Kanak-kanak Dan Sekolah Dasar Kecamatan Pringkuku”. Penelitian tersebut bertujuan untuk menghasilkan sistem informasi pengelolaan Surat Masuk dan Surat Keluar pada unit pelaksanaan teknis taman kanak-kanak dan sekolah dasar kecamatan pringkuku yang efisien dan efektif.

Penelitian sejenis juga dilakukan oleh Muhammad Luqman, namun demikian, penelitian yang penulis lakukan ini juga memiliki perbedaan, faktor pembeda dari penelitian tersebut adalah :

1. Topik pembahasan

Penelitian ini mengangkat pembahasan lebih luas yaitu mengenai sistem informasi surat menyurat di tempat yang lebih luas cakupan data nya. Sedangkan penulis hanya menganai analisis dan perancangan sistem informasi manajemen surat masuk dan surat keluar.

2. Lokasi penelitian Studi kasus diambil dari lokasi penelitian yang berbeda, diaman peneliti sebelumnya menggunakan Pada Bagian Umum Sekretariat Daerah Kabupaten Pacitan, sedangkan pada penelitian ini penulis menggunakan studi kasus pada Kantor Dinas Kependudukan dan Pencatatan Sipil Kota Jambi.

Penelitian yang penulis lakukan memiliki topik permasalahan penelitian sama-sama mengangkat permasalahan mengenai sistem surat menyurat. Penelitian ini memiliki relevansi dengan penelitian Muhammad luqman pada jurnal Sentra Penelitian Engineering dan Edukasi Volume 5 No 3 tahun 2013. Dengan judul " Pembangunan Sistem Informasi Manajemen Surat Masuk dan Surat Keluar Pada Bagian Umum Sekretariat Daerah Kabupaten Pacitan".

Penelitian tersebut bertujuan untuk menghasilkan sistem informasi Manajemen Surat Masuk dan Surat Keluar pada bagian Umum Sekretariat Daerah Kabupaten Pacitan yang dapat membantu dalam pencairan data surat dan mempermudah pemohon surat dalam memonitoring surat yang dikirimnya.

Penelitian lain yang sejenis juga dilakukan oleh Arie Vironica Dan Sukadi, namun demikian, penelitian yang penulis lakukan ini juga memiliki perbedaan, faktor pembeda dari penelitian tersebut adalah :

1. Topik pembahasan

Penelitian ini mengangkat pembahasan rancang bangun surat masuk dan surat keluar, Sedangkan penulis mengenai analisis dan perancangan sistem informasi manajemen surat masuk dan surat keluar.

2. Lokasi penelitian

Studi kasus diambil dari lokasi penelitian yang berbeda, dimana peneliti sebelumnya pada Sekolah Menengah Pertama Negeri 2 Nawangan, sedangkan pada penelitian ini penulis menggunakan studi kasus pada Kantor Dinas Kependudukan dan Pencatatan Sipil Kota Jambi. 
Penelitian yang penulis lakukan memiliki topik permasalahan penelitian sama-sama mengangkat permasalahan mengenai sistem surat menyurat. Penelitian ini memiliki relevansi dengan penelitian Arie Vironica Dan Sukadi pada jurnal Sentra Penelitian Engineering dan Edukasi Volume 5 No 4 - 2013. Dengan judul "Rancang Bangun Aplikasi Pengelolaan Surat Masuk Dan Surat Keluar Pada Sekolah Menengah Pertama Negeri 2 Nawangan". Penelitian tersebut bertujuan untuk menghasilkan sistem informasi pengelolaan surat masuk dan surat keluar pada Sekolah Menengah Pertama Negeri 2 Nawangan.

Dari ketiga penelitian sejenis yang telah penulis uraikan tersebut dapat diketahui bahwa terdapat relevansi dengan penelitian yang ketiga peneliti tersebut lakukan. Relevansi tersebut terletak pada permasalahan penelitian, yaitu sama-sama mengangkat permasalahan mengenai surat masuk dan surat keluar.

Namun demikian juga terdapat perbedaan antara penelitian yang penulis lakukan dengan ketiga penelitian tersebut diatas. Perbedaannya adalah Lokasi Penelitian, penulis mengambil lokasi penelitian pada Kantor Dinas Kependudukan dan Pencatatan Sipil Kota Jambi, sedangkan Siska Wahyu Kartikasari lokasi penelitian di UPT Taman Kanak-kanak dan Sekolah Dasar Kecamatan Pringkuku, penelitian Muhammad Luqman lokasi penelitian di Bagian Umum Sekretariat Daerah Kabupaten Pacitan, dan penelitian yang dilakukan oleh Arie Vironica Dan Sukadi mengambil lokasi penelitian di Sekolah Menengah Pertama Negeri 2 Nawangan.

\section{Metode Penelitian}

Untuk menghasilkan penelitian yang baik dan sesuai dengan sasaran penelitian, maka dibuat sebuah alur penelitian yang sesuai dengan judul penelitian dan berisi langkah-langkah yang dilakukan dalam penelitian. Berikut ini merupakan langkah penelitian yang penulis gambarkan melalui alur penelitian, yaitu:

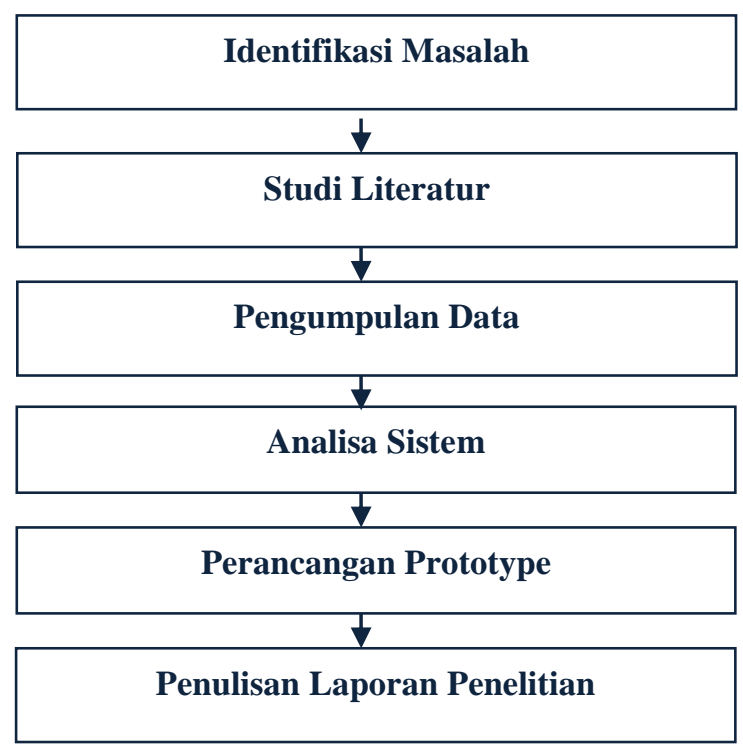

\subsection{Identifikasi Masalah}

Dalam tahap ini, peneliti mengidentifikasi permasalahan yang ada yaitu merumuskan masalah yang akan di teliti. Dengan adanya perumusan masalah, maka penelitian akan menjadi jelas dan terarah.

\subsection{Studi Literatur}

Hal yang pertama kali dilakukan dalam pembuatan tesis ini adalah melakukan kegiatan studi literatur. Kegiatan ini dilakukan dengan maksud mempelajari dan memahami teori-teori yang menjadi pedoman dan referensi guna penyelesaian masalah yang di bahas dalam tesis ini dan mempelajari penelitian yang relevan dengan masalah yang diteliti. 


\subsection{Pengumpulan Data}

Sebagai bahan pendukung yang sangat berguna bagi penulis untuk mencari atau mengumpulkan data yang diperlukan dalam penelitian ini, penulis menggunakan 2 (dua) cara, yaitu :

1. Pengamatan (observation)

Penelitian dengan metode observasi ini dilakukan dengan melakukan pengamatan langsung terhadap objek yang akan diteliti yang bertujuan untuk mengetahui secara langsung mengenai Sistem informasi Manajemen Surat masuk dan Surat Keluar Pada Dinas Kependudukan dan Pencatatan Sipil Kota Jambi.

\section{Wawancara (Interview)}

Penulis melakukan penelitian lapangan dengan cara melakukan wawancara kepada pihak yang berkaitan untuk memperoleh data-data yang dibutuhkan oleh penulis. Hal ini dilakukan agar penulis mengetahui kegiatan apa saja yang dilakukan. Untuk memperoleh data yang akurat serta relevan agar dapat menghasilkan suatu rancangan aplikasi yang sesuai dengan kebutuhan. Wawancara yang dilakukan dengan dua bentuk, yaitu wawancara terstruktur (dilakukan melalui pertanyaanpertanyaan yang telah disiapkan sesuai dengan permasalahan yang akan diteliti). Sedangkan wawancara tidak terstruktur (wawancara dilakukan apabila adanya jawaban berkembang di luar sistem permasalahan).

\subsection{Analisis Sistem}

Pada langkah ini dilakukan analisa terhadap sistem informasi yang sedang berjalan pada Dinas Kependudukan dan Pencatatan Sipil untuk mengetahui masalah yang ada pada Sistem informasi Manajemen Surat Menyurat Pada Dinas Kependudukan dan Pencatatan Sipil, sehingga diketahui apa saja kelemahan dan kekurangan yang terdapat Sistem informasi Manajemen Surat Menyurat Pada Dinas Kependudukan dan Pencatatan Sipil tersebut.

Selain itu juga dilakukan analisa terhadap interaksi-interaksi yang terjadi di dalam Sistem informasi Manajemen Surat Menyurat Pada Dinas Kependudukan dan Pencatatan Sipil tersebut yang nantinya akan digambarkan dalam model UML, yaitu : diagram Use Case, Diagram Class, dan Diagram Activity.

\subsection{Perancangan Prototype}

Pada tahap ini kita merancang usulan sistem yang baru, penulis menggunakan metode pengembangan sistem dengan model Prototype. Prototype adalah sebuah metode pengembangan software yang banyak digunakan pengembang agar dapat saling berinteraksi dengan pelangan selama proses pembuatan sistem dan terdiri dari 5 tahap yang saling terkait atau mempengaruhi yaitu sebagai berikut:

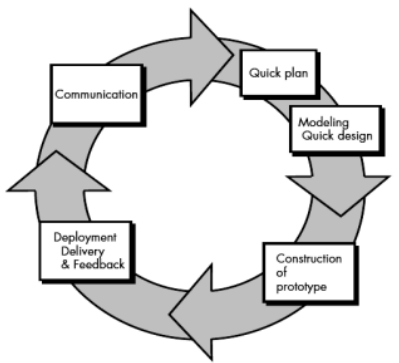

Gambar 3.2 Model Prototype (Pressman, 2010 : 43)

Berdasarkan model prototype yang telah digambarkan diatas, maka dapat diuraikan pembahasan masingmasing tahap dalam model tersebut adalah sebagai berikut:

1. Communication / Komunikasi

Tim pengembang perangkat lunak melakukan pertemuan dengan para stakeholder untuk menentukan kebutuhan perangkat lunak yang saat itu diketahui dan untuk menggambarkan areaarea dimana definisi lebih jauh untuk iterasi selanjutnya.

2. Quick Plan / Perencanaan Secara Cepat

Dalam perencanaan ini iterasi pembuatan prototipe dilakukan secara cepat. Setelah itu dilakukan pemodelan dalam bentuk "rancangan cepat".

3. Modeling Quick Design / Model Rancangan Cepat 
Pada tahap ini memodelkan perencanaan tadi dengan menggunakan beberapa model berorientasi objek dengan menggunakan tools UML yaitu Usecase untuk mendefinisikan fungsi dari sistem, Class Diagram untuk menunjukkan class-class pada sistem, Activity Diagram untuk menggambarkan alur proses bisnis.

4. Construction of Prototype / Pembuatan Prototype

Dalam pembuatan rancangan cepat berdasarkan pada representasi aspek-aspek perangkat lunak yang akan terlihat oleh para end user (misalnya rancangan antarmuka pengguna atau format tampilan). Rancangan cepat merupakan dasar untuk memulai konstruksi pembuatan prototipe.

5. Deployment Deliery \& Feedback / Penyerahan Dan Memberikan Umpan Balik Terhadap Pengembangan

Prototipe kemudian diserahkan kepada para stakeholder untuk mengevaluasi prototype yang telah dibuat sebelumnya dan memberikan umpan-balik yang akan digunakan untuk memperbaiki spesifikasi kebutuhan. Iterasi terjadi saat pengembang melakukan perbaikan terhadap prototipe tersebut.

\subsection{Penulisan Laporan Penelitian}

Pada tahap ini, penulis membuat laporan dari penelitian yang berisikan laporan penelitian terhadap masalah-masalah dan solusi yang ada pada objek yang diteliti oleh penulis yaitu Sistem informasi Manajemen Surat Menyurat Pada Dinas Kependudukan dan Pencatatan Sipil, teori-teori yang diambil penulis yang dijadikan penunjang dalam penelitian, cara penulis dalam melakukan penelitian, hasil penelitian dan analisanya serta beberapa pelengkap dari laporan penelitian.

\section{Pembahasan}

\subsection{Analisis Kebutuhan Sistem}

\subsubsection{Analisis Kebutuhan Fungsional Sistem}

Analisis kebutuhan fungsional sistem digunakan untuk mendefinisikan layanan yang akan disediakan oleh sistem, bagaimana reaksi sistem terhadap input dan apa yang harus dilakukan sistem pada situasi khusus. Analisa kebutuhan-kebutuhan fungsional sistem pada perancangan sistem informasi manajemen Surat Masuk dan Surat Keluar Pada Dinas Kependudukan dan Pencatatan Sipil Kota Jambi, antara lain :

1. Sistem dapat memberikan layanan informasi surat masuk dan surat keluar

2. Sistem dapat memberikan layanan perencanaan aset

3. Sistem dapat memberikan layanan pengadaan aset

4. Sistem dapat memberikan layanan penerimaan aset

5. Sistem dapat memberikan layanan penempatan aset

6. Sistem dapat memberikan layanan pencarian informasi yang berhubungan dengan aset.

7. Sistem dapat memberikan laporan-laporan aset.

Pemodelan fungsional sistem menggambarkan proses atau fungsi yang harus dikerjakan oleh sistem untuk melayani kebutuhan pengguna (user). Fungsi-fungsi yang dapat dilakukan oleh sistem informasi manajemen Sdurat Masuk dan Surat Keluar Pad Dinas Kependudukan dan Pencatatan Sipil Kota Jambi adalah sebagai berikut :

1. Fungsi Login

Fungsi login merupakan fungsi yang dilakukan admin untuk masuk ke dalam sistem dengan menginputkan username dan password. Fungsi Login ini digunakan oleh petugas TU sebagai admin.

2. Fungsi Data Kode Arsip

Fungsi data kode arsip merupakan fungsi yang dilakukan admin untuk menginputkan kode arsip. Terdapat action input, ubah, hapus data kode arsip.

3. Fungsi Data Kode Surat

Fungsi data kode surat merupakan fungsi yang dilakukan admin untuk menginputkan kode surat.

Terdapat action input, ubah, hapus data kode surat.

4. Fungsi Data Kode Pengelola

Fungsi data kode pengelola merupakan fungsi yang dilakukan admin untuk menginputkan kode pengelola surat. Terdapat action input, ubah, hapus data kode pengelola surat.

5. Fungsi Data Surat Masuk 
Fungsi data surat masuk merupakan fungsi yang dilakukan admin untuk menginputkan surat yang masuk ke Dinas kependudukan dan pencatatan sipil kota jambi. Terdapat action input, ubah, hapus, buat lampiran surat masuk.

6. Fungsi Data Surat Keluar

Fungsi data surat keluar merupakan fungsi yang dilakukan admin untuk menginputkan surat yang keluar dari Dinas kependudukan dan pencatatan sipil kota jambi. Terdapat action input, ubah, hapus, buat lampiran surat keluar.

7. Fungsi Membuat Laporan

Fungsi membuat laporan merupakan fungsi yang dilakukan admin untuk melihat dan mencetak laporan berdasarkan kategori laporan rekapitulasi.

8. Mengelola Admin

Fungsi mengelola admin merupakan fungsi yang digunakan oleh admin atau petugas TU untuk mengganti password yang lama ke password yang baru.

9. Fungsi Logout

Fungsi ini digunakan apabila admin telah selesai menggunakan aplikasi tersebut dan ingin keluar dari aplikasi dengan mengklik tombol logout.

\subsubsection{Analisis Kebutuhan Non Fungsional Sistem}

Berdasarkan analisis kebutuhan fungsional sistem yang telah dijelaskan sebelumnya, maka diharapkan sistem yang dirancang mampu memiliki hal-hal tersebut berikut :

1. Usability

Aplikasi memiliki rancangan antar muka sistem mudah digunakan oleh sistem.

2. Security

a. User diberi username dan password

b. Data-data hanya dapat diolah oleh user(admin)

3. Flexibility

a. Kemudahan data dalam mencari data yang dibutuhkan dikarenakan pengorganisasian data yang baik.

b. Kemudahan setiap akan melakukan pencetakan laporan rekapitulasi yang sudah terintegrasi dengan baik.

\subsection{Perancangan Sistem}

\subsubsection{Diagram Use Case}

Alat bantu yang digunakan untuk memodelkan proses bisnis berdasarkan perspektif pengguna sistem berupa Use Case. Use case diagram terdiri atas diagram untuk use case dan actor. Actor merepresentasikan orang yang akan mengoperasikan atau berinteraksi dengan sistem aplikasi.

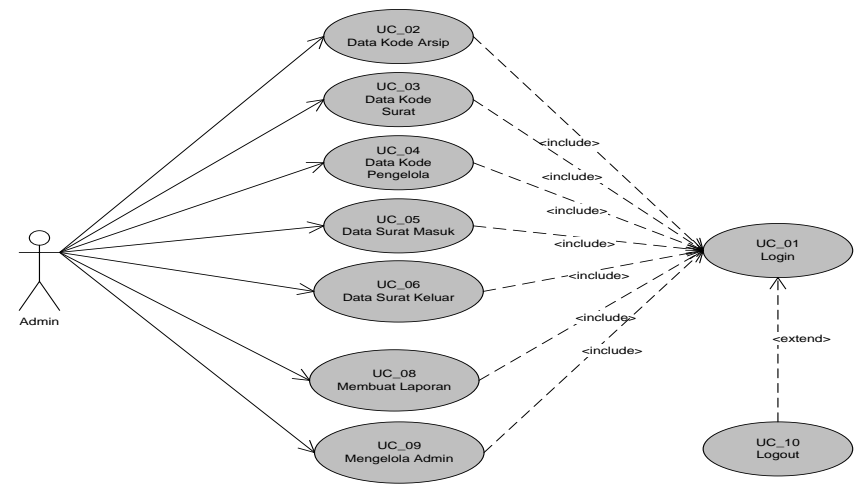

Gambar 4.1 Use Case Diagram [3]

\subsubsection{Activity Diagram}

Jurnal Manajemen Sistem Informasi Vol.4, No.2, Juni 2019 
Berikut adalah penggambaran activity diagram untuk perancangan sistem informasi manajemen aset pada Biro Pengelolaan Barang Milik Daerah Setda Provinsi Jambi pada saat melakukan Login, Pengolahan data-data aset dan Pencetakan laporan-laporan aset dapat dilihat pada gambar berikut ini:

1.Activity Diagram Login

Urutan aktivitas proses login dapat dilihat pada gambar 4.2 berikut :

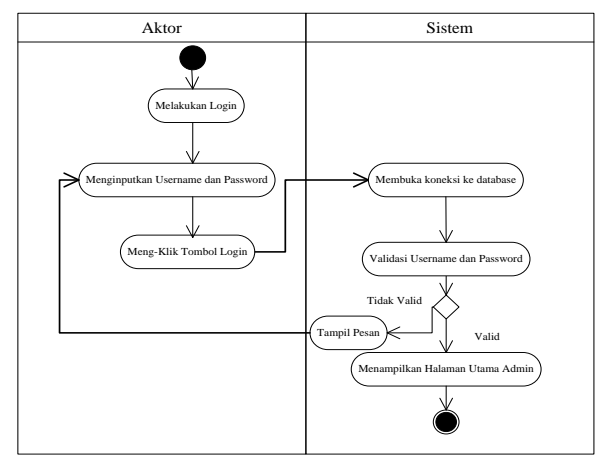

Gambar 4.2 Activity Diagram Login [4]

4.2.2 Activity Diagram Mengelola Kode Arsip

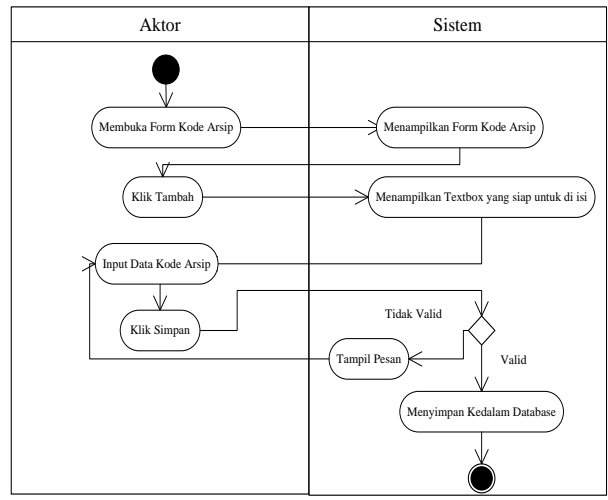

Gambar 4.3 Activity Diagram Mengelola Kode Arsip [5]

\subsubsection{Class Diagram}

Class diagram menggambarkan class berikut perilaku dan keadaan dengan menghubungkannya antar class - class. Pada class diagram akan dijabarkan deskripsi class diagram sebagai berikut

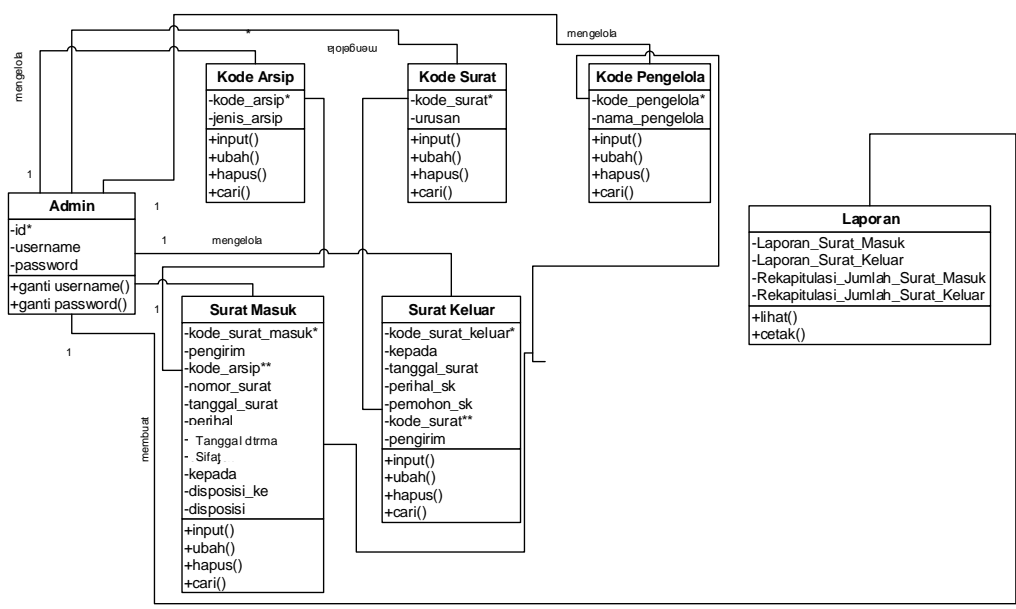

Gambar 4.4 Class Diagram [6] 


\subsection{Rancangan Input dan Output}

Rancangan input dan output merupakan rancangan dari form-form masukan dan tampilan keluaran dari sistem informasi Dinas kependudukan dan pencatatan sipil kota jambi ini. Berikut adalah rancangan Output dan Input dari sistem informasi Dinas kependudukan dan pencatatan sipil kota jambi:

a. Rancangan Masukan Login Admin

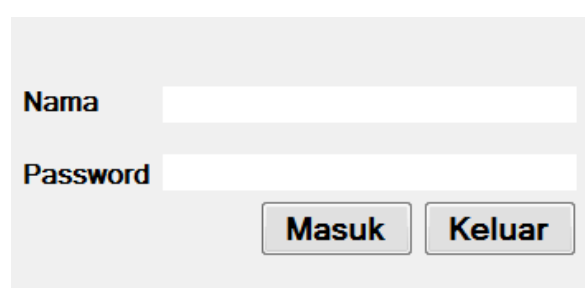

Gambar 4.5 Rancangan Halaman Login[7]

b. Rancangan Menu Utama

Halaman utama adalah halaman yang pertama kali tampil ketika aplikasi diakses oleh admin.

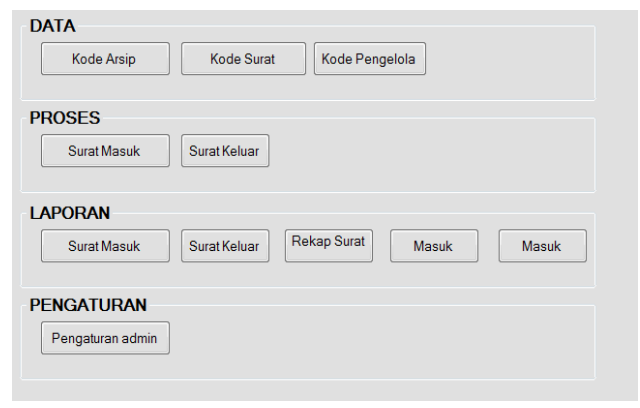

Gambar 4.5 Rancangan Menu Utama [8]

c. Rancangan Tampilan Mengelola Kode Arsip

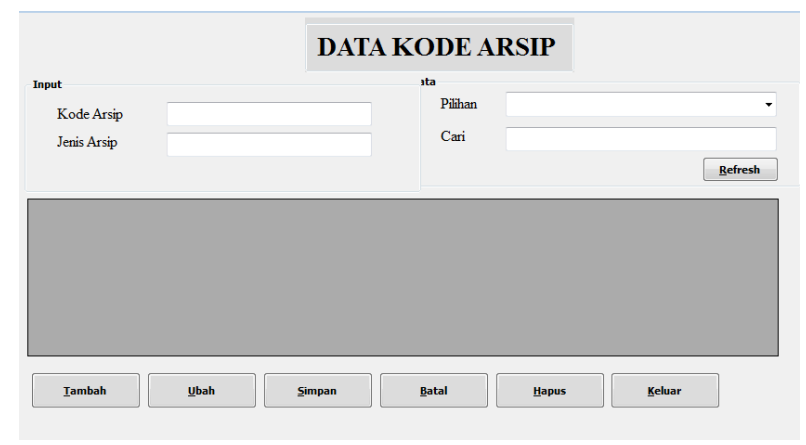

Gambar 4.6 Rancangan Tampilan Mengelola Kode Arsip [9] 
d. Rancangan Tampilan Mengelola Kode Surat

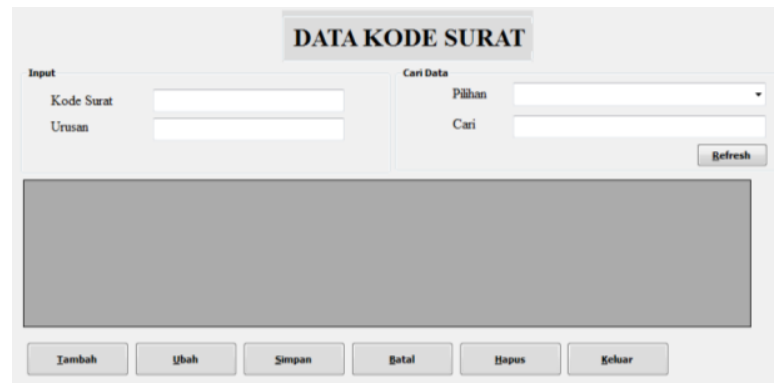

Gambar 4.6 Rancangan Tampilan Mengelola Kode Surat [9]

e. Rancangan Tampilan Mengelola Data Kode Pengelola

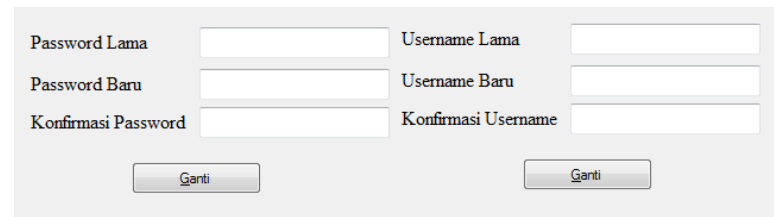

Gambar 4.7 Rancangan Tampilan Mengelola Data Kode Pengelola [10]

f. Rancangan Tampilan Mengelola Data Surat Masuk

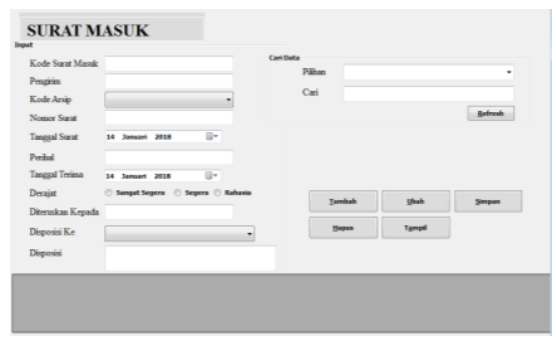

Gambar 4.8 Rancangan Tampilan Mengelola Data Surat Masuk [11]

g. Rancangan Tampilan Mengelola Data Surat Keluar

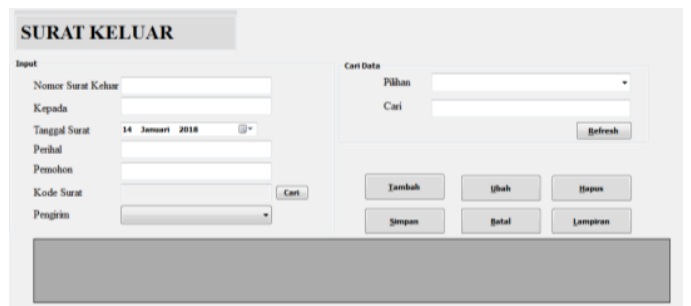

Gambar 4.9 Rancangan Tampilan Mengelola Data Surat Keluar [11]

\section{Kesimpulan dan Saran}

\subsection{Kesimpulan}

Berdasarkan hasil dari analisis dan perancangan sistem informasi managemen surat masuk dan surat keluar pada Dinas kependudukan dan Pencatatan Sipil Kota Jambi dalam penelitian yang telah peneliti lakukan serta berdasarkan pembahasan yang telah di uraikan pada bab - bab sebelumnya maka peneliti 
dapat menarik kesimpulan dari permasalahan yang di hadapi oleh Dinas Kependudukan dan Pencatatan Sipil Kota Jambi sebagai berikut :

1. Pada penelitian ini mempermudah pegawai dalam mengelola data surat masuk dan surat keluar pada Dinas kependudukan dan Pencatatan Sipil Kota Jambi yang lebih baik dan dapat melihat laporan dengan lebih cepat

2. Dengan adanya rancangan surat masuk dan surat keluar ini maka diharapkan dapat memudahkan pengguna dalam melakukan pengolahan data surat masuk dan surat keluar pada Dinas Kependudukan dan Pencatatan Sipil Kota Jambi sebagai solusi pemecahan permasalahan yang ada pada Dinas kependudukan dan Pencatatan Sipil Kota Jambi yang telah dibahas pada bab sebelumnya

\subsection{Saran}

Untuk mencapai tujuan yang di harapkan peneliti memberikan beberapa saran yang di harapkan dapat memberikan manfaat. Adapun saran-saran dari penulis Diharapkan penelitian tersebut antara lain :

1. Diharapkan dapat dikembangkan lebih lanjut dalam bentuk aplikasi

2. Diharapkan dapat dikembangan dalam pembuatan surat elektrik sehingga tidak lagi ada surat dalam bentuk hardcopy

3. Perancangan yang dibuat masih dalam bentuk protoype sehingga saat akan dikembangkan menjadi aplikasi dan diimplementasikan harap dilengkapi lagi sesuai kebutuhan yang ada pada dinas kependudukan dan pencatatan sipil.

\section{Daftar Rujukan}

\section{Paper dalam Jurnal}

[1] Arie Vironica dan Sukadi. 2013. Rancang Bangun Aplikasi Pengelolla Surat Masuk Dan Surat Keluar Pada Sekolah Menengah Pertama Negeri 2 Nawangan. Jurnal sentra Penelitian Engineering dan Edukasi Volume 5 No. 4 -2013

[2] Muhammad luqman. 2013. Pembangunan Sistem Informasi Manajemen Surat Masuk dan Usrat Keluar Pada Bagian Umum Sekretariat Daerah Kabupaten Pacitan.. jurnal Sentra Penelitian Engineering Dan Edukasi Volume 5 No.3.

[3] Nataniel Dengen., dan Heliza Rahmania Hatta., 2009. Perancangan Sistem Informasi Terpadu Pemerintah Daerah Kabupaten Paser. Banjarmasin : Jurnal Informatika Mulawarman.

\section{Buku}

[4] Agung, Leo. 2011. Aplikasi Database Dengan Dreamweaver Dan PHP-Mysql. Yogyakarta : Andi.

[5] Ali, Hapzi. 2010, Sistem Informasi Manajemen Berbasis Teknologi Informasi. Yogyakarta : Hasta Cipta Mandiri.

[6] Arie Vironica Dan Sukadi. 2013. Rancang Bangun Aplikasi Pengelolaan Surat Masuk Dan Surat Keluar Pada Sekolah Menengah Pertama Negeri 2 Nawangan. jurnal Sentra Penelitian Engineering dan Edukasi Volume 5 No 4 - 2013

[7] Dennis, Alan; \& Wixom, Haley Barbara: \& M.Roth, Roberta. 2010. Systems Analysis and Design. Fifth Edition. United States of America : John Wiley \& Sons, Inc.

[8] Darmawan, Deni; \& Fauzi, Kunkun N. 2013. Sistem Informasi Manajemen. Bandung : Remaja Rosdakarya.

[9] Hanif Al Fatta., 2007. Analisis dan Perancangan Sistem Informasi untuk Keunggulan Bersaing Perusahaan dan Organisasi Modern. Yogyakarta : ANDI

[10] Hendrayudi. 2009. VB 2008 Untuk Berbagai Keperluan Pemrograman. Jakarta : PT Elex Media Komputindo.

[11] Kanisius., 2008. Manajemen Administrasi Perkantoran. Yogyakarta : (Anggota IKAPI).

[12] Muhammad luqman. 2013. Pembangunan Sistem Informasi Manajemen Surat Masuk dan Surat Keluar Pada Bagian Umum Sekretariat Daerah Kabupaten Pacitan. jurnal Sentra Penelitian Engineering dan Edukasi Volume 5 No 3.

[13] Nataniel Dengen., dan Heliza Rahmania Hatta., 2009. Perancangan Sistem Informasi Terpadu Pemerintah Daerah Kabupaten Paser. Banjarmasin : Jurnal Informatika Mulawarman. 
[14] Nugroho, Adi. 2010. Rekayasa Perangkat Lunak Berorientasi Objek Dengan Metode USDP (Unified Software Depelopment Process). Yogyakarta : Andi.

[15] Pressman, Roger S. 2010. Rekayasa Perangkat Lunak : Pendekatan Praktisi. Edisi 7. Yogyakarta: Andi.

[16] Priyanto, Hidayatullah. 2012. Visual Basic.Net Membuat Aplikasi Database Program Kreatif. Bandung : Informatika.

[17] Rizky, Soetam. 2011. Konsep Dasar Rekayasa Perangkat Lunak (Software Reengineering). Jakarta : PT.Prestasi Pustakaraya.

[18] Rosa \& Shalahuddin. 2013. Rekayasa Perangkat Lunak Terstruktur Dan Berorientasi Objek. Bandung : Informatika.

[19] Rosa \& Shalahuddin. 2011. Modul Pembelajaran Rekayasa Perangkat Lunak Terstruktur Dan Berorientasi Objek. Bandung : Modula.

[20] Sholiq. 2010. Analisis Dan Perancangan Berorientasi Objek. Bandung : CV.Muara Indah.

[21] Siska wahyu kartikasari. 2011. Sistem Informasi Pengelolaan Surat Masuk dan Surat Keluar Pada Unit Pelaksanaan Teknis Taman Kanak-kanak dan Sekolah Dasar Kecamatan Pringkuku. Sentra Penelitian Engineering dan Edukasi, Volume 3, Nomor 1- ijns.org

[22] Subari; \& Yuswanto. 2008. Panduan Lengkap Pemrograman Visual Basic 6.0. Jakarta : Cerdas Pustaka Publisher.

[23] Sulindawati; \& Muhammad Fathoni. 2010. Pengantar Analisa Perancangan "Sistem”. Jurnal SAINTIKOM. Vol 9 , No 2 Agustus 2010

[24] Sutabri, Tata. 2005. Sistem Informasi Manajemen. Yogyakarta : Andi.

[25] Wardana. 2008. Membuat Aplikasi Berbasis Pendekatan Sistem Dengan Visual Basic. NET 2008. Jakarta : PT Elex Media Komputindo.

[26] Winarno, Wing W. 2006, Sistem Informasi Manajemen. Yogyakarta : UPP (Unit Penerbit Dan Percetakan). 